\title{
O BINÔMIO COMUNICAÇÃO E EDUCACÃO: COEXISTÊNCIA E COMPETIÇÃO
}

\author{
LUIZ R. BUSATO \\ Professor do Institut de la Communication et des Médias -- Universidade Stendhal -- \\ Grenoble3 \\ Membro do Grupo de Pesquisas em Comunicação -- GRESEC \\ França
}

\section{RESUMO}

Este artigo argumenta, inclusive a partir de uma abordagem comunicacional, que a educação sempre serviu-se dos meios técnicos, mas que a situação atual tem uma originalidade: é que todos os destinatários da educação estão mergulhados num universo de tecnologias que impedem o professor de ignorá-las. Por isso, ensinar requer dos professores e responsáveis pela educação um mínimo de cultura e de habilidade tecnológica. É sob essa condição que eles podem orientar os equilíbrios instáveis entre as formas mais tradicionais de ensino e as formas mais tecnicistas. Disso surgem novos modelos de pedagogia que constituem verdadeiros desafios teóricos e práticos para todos os atores que trabalham ou se interessam pela educação.

INFORMÁTICA - EDUCAÇÃO - COMUNICAÇÃO - TECNOLOGIA

Este artigo foi originalmente pronunciado em conferência no Educador'97 - IV Congresso Internacional de Educação, nas sessões organizadas pela professora Vani Kenski, na Faculdade de Educação da USP, em São Paulo, de 5 a 10 de maio de 1997. 


\begin{abstract}
COMMUNICATION AND EDUCATION: COEXISTENCE AND COMPETITION. This paper arguments from a communicational standpoint, that education has constantly used communication technologies. Besides, nowadays, people in teaching positions can no longer pretend to ignore technology, since technology does exist in everyday's life for those they teach. Thus, teaching now requires a minimum technical proficiency, as well as the search for a new balance: traditional teaching models on the one hand; modern, more technology based teaching techniques on the other. As such, this model turns out to be a new challenge to professionnal teachers and to anyone concerned with education, both from a theoretical and practical point of view.
\end{abstract}

O que tem a ver a comunicação com a educação?

A pergunta é antiga. Mas ela volta ritualmente, nesta ordem e na ordem inversa, cada vez que há crise social. Crise de falta ou de abundância; ou de identidade; ou ameaça de revolução.

É o caso hoje: as técnicas de comunicação e de informação estão em expansão rápida, contínua e parecem invadir inelutavelmente todos os espaços, tanto o social como o privado, com uma especial predileção pelo espaço educativo.

A relação entre educação e tecnologias de comunicação é um intrigante-mor da vida dos educadores, mesmo quando ela não implica decisões de apropriação ou de uso pessoal. Porque, para além da pessoa do professor, do diretor de escola, do aluno, ela envolve também aspectos que ultrapassam os problemas exclusivos da educação. Entre medo e euforia, o espaço e as práticas educativas tradicionais, suas representações simbólicas, seus conteúdos, o quadro negro, o livro, as relações com os alunos e o próprio exercício da profissão de professor reagem à técnica; o contato nunca é insignificante. Em sentido contrário, a questão interpela também os comunicadores. É 
claro que os dados imediatos não são os mesmos pois que são concernentes a duas profissões distintas, cada uma com a sua tradição; mas o problema de fundo permanece: comunicadores e educadores estão imersos num mesmo corpo social, ambos aí operam de tal forma que é difícil diferenciar a parte que cabe a um e a que cabe a outro.

O escopo deste artigo é o de recolocar a mesma pergunta e algumas de suas derivações ligadas à revolução numérica e propor uma problematização que, sem ambições de revelar novidades, pretende simplesmente alimentar os debates sempre atuais que ela suscita.

Veremos primeiramente o que pode ser dado como pressuposto na relação entre os dois sistemas sociais, a educação e a comunicação, suas apropriações e usos. Propomos em seguida um retorno sobre a história desse duo ancestral e algumas questões inspiradas pela pressão da oferta, engendrada pelo mercado e pela política, e pela pressão da demanda social. Enfim um apanhado sobre o futuro: síndromes, utopias e mudanças possíveis. No pano de fundo estarão geralmente as situações brasileira e francesa

\section{PRESSUPOSTOS}

Toda discussão sobre técnica e educação deve começar pela constatação de sua existência como fenômenos das sociedades contemporâneas. Essa postura inicial pragmática deve ser considerada aqui como complementar e não como oposta às abordagens críticas produzidas pela filosofia, pela sociopsicologia ou por outras ciências. Ela implica a tentativa de indexar alguns dados da dimensão empírica dos dois sistemas considerados úteis para tratar a questão proposta. Essa indexação pode, por sua vez, adotar posturas críticas de diversas ordens teóricas ou ideológicas que não vamos aprofundar especificamente. 


\section{Enfoque comunicacional, entre outros}

O primeiro pressuposto consiste em aceitar que a educação pode ser estudada partindose de uma ótica transdisciplinar. A transdisciplinaridade apresenta vantagens epistemológicas consideráveis para os dois setores que estudamos aqui. "A transdisciplinaridade designa o que está 'entre' as disciplinas, o que está 'através' das disciplinas e o que está 'além' das disciplinas'. Ela supera os limites da pluridisciplinaridade, definida como "o estudo de um único objeto por várias disciplinas ao mesmo tempo" e os da interdisciplinaridade, definida como "a transferência dos métodos de uma disciplina para outra" (Basarab, 1997. p.48-9).

A primeira vantagem é que a transdisciplinaridade autoriza enfocar a educação a partir de um ponto de vista global e complexo, característica dominante de toda ciência contemporânea. A segunda, é que permite enfocá-la inclusive de um ponto de vista comunicacional.

É claro que o enfoque comunicacional é limitado em razão dos limites da própria disciplina que se autodesigna como "ciência da comunicação e da informação". Esta designação sofre críticas severas de cientistas oriundos de campos tradicionais de investigação para os quais não pode haver ciência onde prevalecem preocupações mais mercadológicas do que propriamente descritivas. A novidade, a abundância teórica, a multiplicidade de objetos da área comunicacional são conhecidas. Deste ponto de vista ela parece excessivamente heterogênea para pretender contribuir positivamente com as discussões sobre educação.

A comunicação não funciona nem se explica a partir de uma teoria geral unitária; ela tem uma tal multiplicidade de objetos que confunde os melhores especialistas, obrigados a recorrer a outras disciplinas. É múltipla dando aos seus suportes, que vão da rodovia e de seus carros ao rádio e seus programas; múltipla por suas linguagens, que vão do registro publicitário ao poema de amor; múltipla por seus atores, que vão do tipógrafo de imprensa ao animador de shows ou ao professor numa sala de aula; 
múltipla nos seus efeitos, que vão da fotografia sobre assassinatos de princesas à ocupação de fazendas provocada pelo discurso de um líder de sem-terras.

Apesar desse polimorfismo e das inquietações que pode suscitar, a comunicação representa uma fonte inesgotável de inspiração para os educadores. Ela pesa consideravelmente em suas atividades e, direta ou indiretamente, exerce influências capazes de transformar um por um todos os elementos que compõem o sistema educativo. Veremos por exemplo que a incursão da macroeconomia na educação é, diretamente, um efeito das evoluções do próprio sistema técnico e econômico da comunicação.

O enfoque comunicacional da educação não exclui todos os outros, mas impõe-se da mesma maneira que os outros na medida em que a educação passa, ela própria, por processos cada vez mais densos de transdisciplinarização.

Em que consiste o enfoque comunicacional?

Veremos ao longo destas páginas alguns dos seus aspectos, mas desde já constatemos que ele designa a possibilidade para o ser humano de contornar o obstáculo fundamental ao conhecimento, representado pela inelutável separação física do ser que pensa e do ser pensado, seja este humano, natural, técnico ou simbólico.

\section{O processo educacional sempre contém elementos de comunicação}

Não há educação sem uso de técnicas; a maioria destas é de natureza substancialmente comunicacional como o sugerem as definições gerais abaixo.

A primeira designa a comunicação como todo ato de relação do indivíduo com os outros indivíduos e com o resto do mundo. Ora, o individuo humano está em relação com alguém ou alguma coisa a partir do momento em que há uma interação. A não ser em raros casos, a interação é a situação mais freqüente da existência humana. 
Uma outra definição, de natureza antropológica como a precedente, diz essencialmente que "a comunicação é o conjunto de atos que, na vida cotidiana, acionam as 'estruturas' que fundam a sociedade, isto é, a cultura... O conjunto das atualizações da cultura nos mil e um gestos da vida cotidiana constitui 'a comunicação"” (Winkin, 1997. p.21).

Apesar do grau abstrato dessa definição, pode-se imaginar as suas consequiências bem concretas, por exemplo, na expressão célebre do grupo de pensadores dito "de Palo Alto", na Califórnia: "Não se pode não comunicar". Um exemplo dado pelo antropólogo Ray Birdwistell, membro desse grupo, pode esclarecer o caso: "O estudante que nunca esperou uma chamada telefônica numa residência universitária [numa sexta-feira à tarde] não sabe o quanto um telefone silencioso pode fazer barulho" (Birdwistell, 1997. p.20). Para esse autor a comunicação não se limita aos atos intencionais,

nem sequer à mensagem, nem ainda sequer ao intercâmbio e à interação. Ela inclui também o sistema e o contexto que a tornam possível e que podem transformar uma não occorrência informativa [um telefone mudo] no equivalente de uma mensagem explícita . (p.21-2)

Segundo Dell Hymes (1997), em certas culturas admite-se que os deuses falam aos homens por intermédio do trovão e que as pedras são sinais dispostos pelos deuses no deserto para ajudar os homens a atravessá-lo. Neste sentido, diz Hymes, todos os fatos têm a ver com a comunicação, e neste caso, deve-se inserir nela também os atores aos quais os membros de uma comunidade atribuem intenções comunicativas, como os deuses, os mortos, os animais, as árvores. Isto significa também que até em culturas que dispõem de um repertório de comunicação limitado, este será sempre muito mais vasto do que o simples uso da palavra.

Essa definição ampla da comunicação inclui necessáriamente a educação; mas ela é global demais e pouco operatória. Na realidade ela complica tanto quanto explica. Um 
observador distraído, em face do mundo entulhado de objetos comunicacionais, pode simplesmente decidir que "tudo é comunicação". Tal postura equivale a um niilismo.

Há evidentemente multiplicidade de abordagems conceituais da comunicação. Não se poderia expô-las todas aqui mas é útil lembrar que o fato de criticá-las e de se tentar construir simbolicamente a comunicação não pode ocultar a sua outra dimensão, fenomenal, patente na infinidade de práticas, produtos, organismos, leis, usuários, produtores. Se os aparatos técnicos de comunicação não são "entes da natureza”, eles não são também somente "seres ideais". Eles fazem parte da ecologia humana contemporânea e não foram criados por e para nada.

Deve-se também considerar que o ato educativo é uma forma particular de comunicação: o professor não é apenas uma correia de transmissão de conhecimentos que ele vai buscar numa prateleira e depositar na carteira dos alunos. Pelo contrário, ele é um comunicador de saberes e sem as técnicas e as artes de comunicá-los não teria nenhum sucesso. Um dos sentidos do termo "comunicação" é precisamente “transmissão".

Afinal, desde sempre a educação se apoderou das últimas técnicas de comunicação para operacionalizar os seus fins. Mencionemos aqui simplesmente o caso dos retóricos Corax e Thisias:

Pelos anos 485 A.C. dois tiranos sicilianos, Gelão et Híeron ocuparam as propriedades dos habitantes de Siracusa para dá-las aos mercenários que haviam empregado em suas guerras. Quando esses tiranos foram destituídos após uma insurreição popular e a população quis voltar à situação anterior, houve inúmeros processos para que cada família pudesse recuperar os seus bens. Esses processos acabaram inspirando dois "advogados locais", Corax e Thisias, que criaram um ensino específico (Breton, Proulx, 1991. p.30-1),

cujo conteúdo seria nomeado "retórica". Era a invenção mais recente: uma série de regras capazes de aumentar consideravelmente o poder operatório da linguagem. A retórica foi imediatamente "importada" pelos gregos que a introduziram como matéria 
central dos "currículos" escolares da época. Ela fez a fortuna dos retores e dos sofistas, transformados em "técnicos no uso da linguagem", capazes de produzir discursos em escala industrial e para todo tipo de clientes e situações.

Na realidade, a retórica como Nova Tecnologia de Comunicação e de Informação NTCI -- da época, consistia em dar à palavra oral o caráter de um discurso organizado, hierarquizado em sequiências argumentativas, de maneira a convencer os ouvintes da validade do que era dito.

Daí surgiram novas funções para a linguagem; a função argumentativa, antes explorada como meio "científico" de conhecimento, passou a ser utilizada também como meio "pragmático", capaz de mudar sensivelmente as representações sociais, as maneiras de exercer a política, etc. Ela engendrou também novos interesses pela gramática e pela sintaxe e esclareceu as diferenças entre usos "espontâneos" da linguagem e usos "técnicos".

Digamos que, ainda hoje, quando ensinamos os alunos a organizar uma redação sobre o tripé chamado exórdio, corpo e peroração, estamos utilizando uma técnica de comunicação educativa que tem 2.500 anos. Mas é claro que a noção de retórica mudou muito nos séculos seguintes, embora os sofistas não tenham desaparecido...

\section{A técnica como auxiliar da educação}

Os meios de comunicação sensoriais (naturais) ou técnicos (artificiais) atuam de maneira complementar no processo de educação. Excetuando casos específicos, não são o seu objeto, nem a sua substância, nem a sua finalidade.

O estatuto de auxiliar não reduz os mediadores (tanto os técnicos como os humanos, na medida em que o professor é também um mediador) a algo secundário. Pelo contrário, sem eles não há educação eficaz, sobretudo se se trata de educação de massas. 
Decorre que a presença ou a ausência de meios técnicos de comunicação e de informação na educação não são equivalentes e que a presença desse ou daquele meio particular de comunicação em lugar de outros também não é indiferente, nem no que toca às performances do processo pedagógico nem no que toca aos seus resultados. Se o fossem, teríamos que buscar outras razões para explicar o apego mais ou menos entusiástico e ciclicamente frenético dos professores (como de todos os atores educativos) às tecnologias. Ora, o recurso às tecnologias não é novo, pois ele é contemporâneo à invenção da educação nas civilizações ditas primitivas da Babilonia, do Egito, da Índia... Globalmente todas as teorias pedagógicas se confrontaram com duas questões cruciais cada vez que se tratou de posicionar o estatuto das tecnologias: uma, de natureza esquizofrênica, que opõe uso e não-uso e outra, de natureza funcional, que opõe produção e não-produção de resultados. Hoje continuamos colocando-nos as mesmas questões e muitas outras que o desenvolvimento extensivo e pregnante das tecnologias e da educação acarretaram. Mas permanece sempre essa, em pano de fundo: qual é o lugar ideal das tecnologias dentro do sistema e das práticas educativas?

Constata-se que mesmo os educadores que conseguem enquadrá-las num estatuto claro de recurso auxiliar não conseguem impedir que elas produzam efeitos que o ultrapassam. Com o agravante de que elas seguem leis complexas de efetivação histórica que obscurecem até os exercícios mais sofisticados de previsão. Por exemplo, o professor é levado a fazer certas mise-en-scènes pedagógicas dos seus cursos, a partir do momento em que ele lança mão de recursos técnicos não tradicionais; e estes, por natureza, visíveis e sedutores, acabam freqüentemente ocupando a frente do palco e ocultando o sentido fundamental da peça, os conteúdos próprios do curso.

\section{As fronteiras das NTCIs}

Tecnologias de informação e de comunicação -- TIC -- é uma expressão que designa todos os instrumentos que veiculam mensagens imateriais (imagens, sons, seqüências 
de signos que podem ser letras, notas de música, cores, ordens para a paginação de um documento etc.). A expressão Novas Tecnologias de Comunicação e de Informação introduz o elemento de novidade, que discutiremos mais adiante. ${ }^{1}$

O uso da sigla NTCI não significa adesão a todas as ideologias que se ampararam nela. Uma dessas ideologias, em particular, pretende instituir o setor da informaçãocomunicação como motor da sociedade moderna, panacéia para as deficiências do seu funcionamento, explicação e recurso para a resolução de todos os conflitos.

Nesse amálgama está também o professor. Ele é um comunicador, e desse ponto de vista pode ser considerado como ator do sistema comunicacional. Mas tanto ele, como a escola em geral, não são apenas comunicadores.

Eles problematizam o saber, põem-no em perspectiva para que o aluno possa, por sua vez, dominá-lo. “A informação em si não é o conhecimento, o conhecimento em si não é o saber, e o saber escolar em si não é a totalidade do saber, mas apenas seleção e reinterpretação dos conhecimentos" (Dieuzeide, 1994. p.247) cuja aquisição é julgada indispensável para a realização pessoal, social e profissional daquele que aprende. As NTCIs, que mudam fundamentalmente a organização dos saberes, não mudaram ainda as leis da aprendizagem; e estas nos ensinam (quer sejamos cognitivistas brunerianos, vitgostkyanos, behavioristas, pavlovianos ou watsonianos) que o homem aprende, essencialmente, pelo contato direto com outros homens. Isso implica, por exemplo, que a aprendizagem precisa de uma categoria de tempo que não coincide necessariamente com aquela que predomina no sistema técnico. As NTCIs aparecem aqui mais uma vez como auxiliares, não como substitutos.

\footnotetext{
${ }^{1}$ Técnica é o conjunto de procedimentos ou instrumentos utilizados para se obter um resultado qualquer (no início tratava-se de obter a produção de bens materiais); tecnologia é o estudo sobre o uso ou emprego dos recursos, aparelhos, máquinas, materiais visando uma ação predefinida e o estudo de seus efeitos. Tecnologia educacional é o acionamento racional de uma ou várias técnicas a fim de obter um resultado educativo e, além disso, discurso, valores e efeitos ligados a essas práticas (Dieuzeide, 1994. p.12).
} 
A defesa das NTCIs na escola não nos autoriza, por exemplo, a invocar a necessidade do aumento dos conteúdos curriculares sob pretexto de que há um crescimento exponencial dos dados científicos disponíveis e uma grande facilidade de acesso a eles. Nem a utilizá-las -- como ocorre com freqüência -- para tentar reanimar uma instituição escolar em dificuldade, para estimular o interesse dos jovens, ou para desbloquear as relações entre docentes e alunos, quando não, para permitir ao docente resolver com maior facilidade os impasses da sua profissão. Seria ineficaz encarar as NTCIs como recurso milagroso, capaz de resolver as desigualdades ou conflitos de poder dentro da sociedade, das empresas e mesmo da escola.

As NTCIs podem, pelo contrário, contribuir diretamente para os objetivos fundamentais desse indispensável sistema de serviço social que é a educação, e que consiste em transmitir ao maior número possível de crianças, jovens e adultos a maior quantidade possível de conhecimentos organizados. Elas são um recurso privilegiado a serviço da educação; não podem servir de terapia para todos os males da sociedade, ainda menos, para as falhas de seu sistema escolar.

\section{O efeito de novidade das NTCIs}

É extremamente difícil, se não utópico, pretender fazer o inventário de todas as mutações reais ou supostas, induzidas pelas técnicas de comunicação e informação. Pode-se entretanto admitir, como sugerimos, que elas existem por algum motivo.

No quadro dessas reflexões podemos, por exemplo, tentar identificar quais são as novidades expressivas ocorridas com o advento da informática.O que é que ela traz de realmente novo?

O termo "novo" é útilizado aqui não como um qualificativo absoluto das NTCIs mas unicamente como um ponto de referência em relação ao que existia antes². Esse

\footnotetext{
${ }^{2}$ Há entretanto que se distinguir entre a História das técnicas de comunicação e a História das técnicas de comunicação aplicadas à educação.
} 
qualificativo não pode ser aplicado impunemente a produtos gerados por mutações de outros produtos ou práticas anteriores e que, na época atual, não param de se multiplicar e de se transformar.

Os termos nouvelle vague, nouveau roman, "cinema novo", "nova cozinha", nouveaux philosophes contribuem para dar ao termo "novas tecnologias educacionais" um caráter ambíguo. Na realidade, é dificil traçar uma linha clara de separação entre o novo e o velho em um campo no qual é preciso, sobretudo, captar o movimento contínuo com ou sem rupturas técnicas.

O critério utilizado para definir as "novas tecnologias" é primeiramente de natureza técnica. Em segundo lugar, são levados em conta elementos mais amplos -- mas não menos pertinentes -- como as estratégias de apropriação e de uso pelos cidadãos.

Em todo caso, é assim que se apresentam, aparentemente, as técnicas: a demanda seguindo a oferta. Desse modo, o rádio, liberado pela freqüência modulada, mais ouvido hoje nos walkmans, ou nos carros, do que nas casas, e até útilizado em escolas como rádio de estabelecimento, permanece na categoria das paleotécnicas, na expressão de Henri Dieuzeide, "rejuvenescido", mas não concebível como uma técnica nova.

As paleotécnicas são bastante estáveis mas não imóveis; as novas são evolutivas e estão sempre em renovação.

Para efeitos práticos, Henri Dieuzeide (1994) propõe que os educadores considerem como "novas" as técnicas que contêm três características:

a. aumento considerável de velocidade e de potência na capacidade de registrar, estocar e representar a informação escrita, sonora e visual... graças à miniaturização, à portabilidade, à digitalização e à compressão (um CDRom pode conter um bilhão de bytes ou toda a Enciclopédia Britânica -- sem as imagens por enquanto); 
Conseqüência: aumento constante da presença de mensagens textuais, sonoras e visuais na vida cotidiana.

b. capacidade de manipulação imediata da informação, e desenvolvimento de processos interativos (por exemplo a consulta de 54 mil imagens estocadas num videodisco, seja em seqüências fixas ou em movimento, como no cinema. E vai-se para o data videodisco -- DVD -- de 17,5 gigabytes);

Conseqüência: relação mais pessoal e dinâmica do usuário com a informação e suas fontes.

c. o deslocamento (ou "deslocalização", ou perda das referências territoriais locais com a conseqüente aquisição de referências de natureza cada vez mais universal), graças à telecomunicação ou à transmissão de dados digitais ou analógicos a grande distância, por redes de cabos, satélites, emissores hertzianos, fibras que tornam as conexões possíveis entre máquinas e pessoas, viabilizando intercâmbios e consultas;

Consequiência: ubiquidade e instantaneidade.

A velocidade no processamento da informação pode, com efeito, ser entendida como uma novidade real e isso não se atribui somente às novas terminologias que a designam. O que a máquina digital mudou em relação aos modos técnicos ou mentais tradicionais de tratamento da informação é a velocidade com que opera. Ainda assim temos de admitir que a comparação entre cérebro e computador contém todas as distorções possíveis que os próprios criadores do conceito computacional já alinhavam. Note-se, por exemplo, que o computador Deep Blue, programado para jogar xadrez, perdeu para o campeão mundial Gary Casparov em 1995. Nessa data, o computador era equipado para efetuar 2 milhões de cálculos por segundo. Dois anos depois, essa capacidade foi ampliada para 4 milhões de cálculos por segundo, e o computador ganhou a partida. No entanto, tais fatos não permitem afirmar que o limite de cálculo do cérebro está entre 2 e 4 milhões de operações por segundo, que o fato de o 
computador ganhar ou perder de um jogador humano é indicativo das capacidades recíprocas, ou, ainda, que a forma de cálculo é équivalente entre os dois "cérebros".

Este exemplo não suprime portanto a real superioridade do computador para calcular a trajetória de um veículo espacial. Essa superioridade é entretanto redutível a um só elemento: a velocidade de cálculo. É ela a primeira grande verdadeira mudança introduzida pela máquina digital.

A segunda revolução é a ubiquiidade. O dispositivo tecnológico, uma vez implantado, tem uma capacidade de ubicação do usuário extremamente poderosa. "Capacidade para suprimir as distâncias" é uma imagem, com certeza, mas indica que o computador ligado em redes não tem mais os mesmos limites espaciais aos quais nossas culturas estavam acostumadas. Não se trata ainda de redução física, mas simbólica (poder falar em tempo real com alguém situado a mil quilômetros não suprime a distância de mil quilômetros... simplesmente se descobriu um meio para superá-la sem deslocamento físico). O interessante é que tudo funciona como se houvesse verdadeira supressão das distâncias.

A terceira inovação é a interatividade, ou capacidade de manipulação.

Interatividade também sempre existiu na relação face a face entre pessoas ou entre pessoas e outras fontes de informação, mas não na relação em que está envolvido o fator distância.

Antes de voltarmos a essas questões, podemos concluir com estas perguntas: as novas tecnologias criam realmente novas situações pedagógicas? Será que permitem atingir de maneira nova ou inovadora os objetivos tradicionais do sistema educacional: aprendizagem, motivação, aquisição de habilidades, memória etc.? A aparição das NTCIs coincide ou não com a formulação de novos objetivos não só no setor próprio da educação como também na expressão social dos seus objetivos? E enfim: será que 
elas estimulam o aparecimento de novas estratégias pedagógicas capazes de favorecer os alunos desfavorecidos ou excluídos no sistema escolar?

A conseqüência dessas novidades nos leva a distinguir de uma outra maneira os dois setores, como mostra o quadro a seguir:

\section{QUADRO 1}

\section{DISTINÇÕES ENTRE INFORMAÇÃO E ENSINO}

\begin{tabular}{|l|l|l|}
\hline $\begin{array}{l}\text { Conceitos } \\
\text { articulados } \\
\text { entre si }\end{array}$ & $\begin{array}{l}\text { que recobrem atividades intelectuais } \\
\text { radicalmente diferentes }\end{array}$ & $\begin{array}{l}\text { e propõem práticas } \\
\text { pedagógicas de complexidade } \\
\text { crescente }\end{array}$ \\
\hline Informação & $\begin{array}{l}\text { Fluxo de unidades brutas, descontínuas, } \\
\text { instantâneas, que se devem colher, } \\
\text { estocar e classificar ("os dados') }\end{array}$ & Mediatecas, bancos de dados \\
\hline Conhecimento & $\begin{array}{l}\text { Estabelecimento de coerências, } \\
\text { organização e formatização dos dados } \\
\text { de acordo com critérios de utilidade, } \\
\text { de adequação, de confiabilidade, etc. }\end{array}$ & $\begin{array}{l}\text { Enciclopédias, CDRoms, } \\
\text { sistemas inteligentes }\end{array}$ \\
\hline $\begin{array}{l}\text { Saber (ou } \\
\text { competência) }\end{array}$ & $\begin{array}{l}\text { Resultado de um trabalho individual, } \\
\text { geralmente de aquisição de } \\
\text { conhecimentos (memorização, } \\
\text { integração, reutilização) }\end{array}$ & $\begin{array}{l}\text { Algoritmo (ou heurística) } \\
\text { para a resolução de } \\
\text { problemas } \\
\text { complexos }\end{array}$ \\
\hline $\begin{array}{l}\text { Programa (ou } \\
\text { saber) escolar }\end{array}$ & $\begin{array}{l}\text { Seleção e articulação de conhecimentos } \\
\text { a adquirir (disciplinas) por meio da } \\
\text { instituição escolar correspondentes aos } \\
\text { objetivos que lhe são fixados }\end{array}$ & $\begin{array}{l}\text { Manual didático, Centro de } \\
\text { Documentação }\end{array}$ \\
\hline Ensino & $\begin{array}{l}\text { Problematização do “saber escolar"' } \\
\text { pela negociação contínua entre alunos e } \\
\text { professores sobre os métodos e os } \\
\text { conteúdos, a partir das informações } \\
\text { veiculadas pelo sistema social em geral } \\
\text { e pela escola em particular }\end{array}$ & $\begin{array}{l}\text { Experimentação em laboratório, } \\
\text { individualização pelo } \\
\text { computador, leitura crítica da } \\
\text { imagem, análise textual }\end{array}$ \\
\hline
\end{tabular}

Fonte: Adaptação a partir de Dieuzeide, 1994. p. 23. 


\section{HISTÓRIA DAS NTCIs NA EDUCAÇÃo}

\section{Caminhos cruzados}

Como e quando a comunicação entrou na esfera da educação? $\mathrm{O}$ educador está acostumado a indagar sobre as relações entre ambas mas o faz geralmente a partir de uma ótica que põe no centro a educação. Essa maneira auto-referente de ver as coisas acaba obscurecendo o próprio campo da educação, pois se perde de vista que os dois campos, apesar de ligados intimamente quando considerados como partes do sistema social global, são também estrutural, funcional, histórica e teleologicamente muito distintos. Portanto, é legítimo descentrar os termos da pergunta para tentar ver a educação "de fora", ou seja, do ponto de vista da comunicação.

A história da comunicação é recente (menos de cem anos) se levarmos em conta os seus apetrechos teóricos e eletroeletrônicos ${ }^{3}$. Na fase atual ela esbarrou na educação da mesma maneira que nas fases precedentes. Mas, de maneira mais intensa do que antes, a comunicação acabou por incorporar a educação nos seus esquemas interpretativos e operacionais.

Uma das interpretações dominantes dessa junção é a teoria da legitimação das técnicas de comunicação pela educação ${ }^{4}$. Segundo esse ponto de vista, o interesse da comunicação pela educação é sobretudo utilitário: legitimar-se para a opinião e para os poderes públicos mediante uma associação (que tem freqüentemente um caráter

${ }^{3}$ Historicamente, todas as invenções comunicacionais foram de imediato investidas na educação. Assim, a invenção do alfabeto foi logo integrada no aprendizado da escrita, como a invenção da tipografia foi imediatamente empregada na universidade da Idade Média. O mesmo se deu com o surgimento da retórica, de tal maneira que ela foi incorporada aos programas escolares da Grécia ao mesmo título que a filosofia e as artes, conteúdos do currículo nuclear local da época. Nos programas escolares latinos o trivium, que continha as matérias literárias, incluiu a retórica, enquanto no quadrivium, foram incluídas as matérias técnicas referentes às disciplinas científicas e médicas.

${ }^{4}$ Num trabalho de 1979, estudamos, com Jacques Perriault, a introdução da técnica de projeções de slides em suporte de vidro no sistema educacional francês de 1885-86. Constatamos que, vinda das feiras populares e pouco cotada nos meios acadêmicos, essa tecnologia beneficiou-se da conjunção de fatores políticos, financeiros e industriais que acabaram dando-lhe uma legitimidade social e uma expansão consideráveis. Ver Busato, 1979. 
retórico e parasitário) com a educação, sistema social pré-existente e fortemente legitimado. Esse processo acompanha praticamente todas as inovações técnicas ${ }^{5}$. O computador e seus derivados não escaparam a esse esquema.

Entretanto, a teoria da legitimação evolui. Primeiramente, porque a expansão da comunicação e a onipresença dos meios técnicos acabou fazendo com que estes fossem admitidos, estudados, interpretados como um fato social positivo (no sentido da sociologia comtiana). Isso significa que a tecnologia ultrapassou os limites críticos de aceitação social, chegou a um alto ponto de maturidade e autonomia. As técnicas de marketing substituíram parcialmente o sistema educacional nessa obra (sempre mais necessária em razão dos custos) de avaliação prévia da aceitação da oferta pela demanda ${ }^{6}$.

Simultaneamente, a educação entrou em crise. Crise de identidade, finalidade, monopólio, crise econômica, de representação... e só lhe falta entrar, por sua vez, em crise de legitimidade.

Finalmente, a associação da comunicação com a educação produziu um olhar novo sobre a educação e permitiu interações inimagináveis mesmo nas épocas mais gloriosas do audiovisual educativo. Os educadores têm entretanto interesse em manter uma atitude vigilante em relação à comunicação e à sua imensa capacidade de sedução e de alienação. Caso contrário, esbarramos outra vez, e não necessariamente por razões

${ }^{5}$ Um exemplo de caricatura, mas não totalmente fictício, é o das cerimônias de inauguração das primeiras televisões brasileiras (1950, TV Tupi de São Paulo; 1951, TV Tupi do Rio de Janeiro): Assis Chateubriand, o genial fundador, importa os equipamentos dos Estados Unidos, instala no Rio de Janeiro alguns receptores, convida algumas autoridades civis, religiosas e militares, faz um discurso inaugural cheio de humanismo e de esperança no progresso e no fim do analfabetismo, e acaba transmitindo ali mesmo as primeiras imagens de futebol. A análise do conjunto de símbolos aparece, a posteriori, como uma predição do que seriam os usos desse meio na sua fase de maturidade.

"Uma "prova" da expansão das técnicas de comunicação foi dada pelo presidente norte-americano Bill Clinton, em seu discurso sobre a situação do país, em março de 1997. ele confirmou ali o que os especialistas do trabalho já afirmavam há anos: que mais de $50 \%$ da mão-de-obra do país está ocupada em tarefas ligadas à comunicação e à informação. Mesmo se retorquirmos que a definição de comunicação é, neste caso, generosamente ampla, o indício vale. 
filosóficas, na encruzilhada das escolhas impossíveis: a comunicação que exclui a educação e reciprocamente, a comunicação que "devora" a educação, a educação que ignora a comunicação. A boa combinação parece ser outra: comunicação e educação se completam numa obra educativa comum.

Da longa trajetória dos dois sistemas concorrentes, pode-se constatar hoje que a educação integrou a comunicação e suas práticas com mais serenidade e pôde, assim, retomar o caminho, ainda longo com certeza, daquilo que lhe é essencial, o aluno, os conteúdos, a transmissão pedagógica dos saberes e, finalmente, uma concepção mais global do processo educacional e dos seus atores. Concomitantemente, a comunicação acabou incluindo a educação como um de seus campos privilegiados, freqüentemente motivada pela economia e pelo mercado mas não unicamente por isso ${ }^{7}$.

\section{Quatro datas-chave}

A história recente das tecnologias educativas pode resumir-se em quatro datas, todas recentes:

1950-1975: O pólo audiovisual já está constituído.Audiovisual designa o conjunto dos recursos de apresentação visual e sonora utilizados no ensino. Ele comportou essencialmente o cinema, o rádio e o disco, a fotografia e a televisão.

1975: Constituição das NTCIs com o desenvolvimento da microinformática; ela se posiciona junto ao audiovisual, e torna-se seu maior concorrente técnico.

\footnotetext{
${ }^{7}$ Constata-se, por exemplo, que nos países em que a educação foi objeto constante do engajamento do Estado, a comunicação se comporta com mais clareza em relação ã educação do que em países nos quais as políticas educacionais foram caóticas, incertas, vacilanates entre o "todo comunicacional" e o "todo educacional". Se opusermos, por exemplo, países como os da Escandinávia e o Brasil constataremos que nos primeiros os alunos consomem menos produtos de massa do que no Brasil, e que o consumo deles aqui é menos produtivo para a educação do que lá. A interpenetração dos sistemas, quando eles têm legitimidade e visibilidade sociais fortes é benéfica a ambos.
} 
1980: Desenvolvimento das telecomunicações: seus instrumentos (telefax, satélites, redes de cabos etc.) aceleraram a abertura da escola ao mundo exterior.

1990: Fusão do audiovisual com a informática, cujo resultado é a concentração de quase todas as técnicas de comunicação e de informação num único suporte, o computador. Inversamente, a grande virada tecnológica deste final de década e de século é a "diversificação" do computador que passa do estatuto de "multimeio" (agregado de diversos meios autônomos) para o de "unimeio", (suporte novo, cujas múltiplas funcionalidades compõem um todo único e coerente). Essa diversificação que já foi muito rápida em si, pois que as primeiras grandes convergências ocorreram nos anos setenta, continua evoluindo no sentido de uma multiplicação deste último tipo de suporte, o que vêm mudar consideravelmente a paisagem social das tecnologias. É assim que vemos computadores servindo de telefones portáteis, com acesso à Internet, videofonia e outras funcionalidades bem diferentes das do celular dos anos oitenta. Na França criou-se um neologismo para designar esse aparelho, “ordiphone", associação de ordinateur e téléphone. O campus virtual de Grenoble já está pensando no uso desse aparelho para certos fins de ensino.

Veremos mais adiante algumas propostas suplementares que indicam que, no período contemporâneo, houve uma fusão em muitos pontos do duo comunicação/educação, o que resultou na criação de zonas cada vez maiores de interdependência, onde antes só havia interação mais ou menos voluntarista.

\section{QUESTÕES INSTRUMENTAIS}

A situação atual de interdependência recíproca entre comunicação e educação tem uma conseqüência de porte: o educador deve agora adquirir uma dose mínima de cultura técnica instrumentalizável na prática pedagógica. Não se afirma que cada docente deve 
necessariamente ser especialista -- de ciberespaços ou de programação de computador - mas, simplesmente, que não se pode, ao longo de uma carreira dedicada à educação, ignorar as tecnologias. No mínimo, deve-se levar em conta que as NTCIs têm virtudes, defeitos e repercussões sociais profundas.

Essa "obrigação moral" coloca imediatamente a questão de como evitar que a introdução maciça das NTCIs na escola acabe reforçando a dualidade social, excluindo todos os que não têm acesso a ela. Esse problema é na verdade o mais importante atualmente; contém no seu bojo todos os ingredientes do embate político, cultural e industrial do século que se colocam para os que estão envolvidos com a educação.

Existe uma objeção de bom senso a essa posição, às vezes taxada de conformista; ela afirma que de nada adianta orientar os sistemas educacionais para a complementaridade mediática porque uma boa parte dos alunos, e das escolas, não têm acesso aos meios mais sofisticados de comunicação. Na realidade esse argumento não leva em conta um fato fundamental ligado às tecnologias, ou seja: que, mesmo não tendo computador, ou televisão, ou rádio, nem em casa nem na escola, os jovens de todos os meios socioeconômicos e culturais pensam com estruturas mentais e cognitivas bem semelhantes às das NTCIs (Busato, 1982). Esta questão nos remete outra vez para o tema dos efeitos dos meios técnicos de comunicação e de informação. Já vimos que, após cinqüenta anos de preocupações obsessivas com essa questão, chega-se sempre à mesma conclusão geral: enquanto especialistas e opinadores de todo tipo debatem para saber, por exemplo, se a violência na televisão produz a violência social, outras mudanças profundas estão se produzindo na ordem das representações, do pensamento e das linguagens (Citelli, 1997. p.27). Claro que essas mudanças ocorrem de maneira mais forte nos grupos sociais em que o consumo é mais intenso, mas também, e de maneira aguda, nos meios de consumo moderado e até nos meios sociais que não apresentam um consumo direto regular. Só ficam excluídos do universo tecnológico as populações realmente desligadas, e elas são cada dia menos numerosas. Um exemplo que não tem nada a ver com ficção científica: o Parlamento da região 
autônoma canadense dos Esquimós funciona quase exclusivamente via Internet. As aldeias não estão ligadas por nenhuma estrada transitável, o território é extenso, e o essencial da política regional se faz por conexão em rede informática. Os "excluídos da comunicação" não estão na realidade excluídos da cultura global produzida ou induzida pela comunicação.

Quais seriam os elementos de uma cultura instrumental das NTCIs para os educadores? Pode-se sugerir, sem nenhuma intenção de esgotar o assunto, algumas possibilidades de resposta centradas na necessária discriminação de uso das técnicas em sala de aula e no paradigma informático. É claro que poderíamos também colocar outras questões igualmente importantes como a do novo estatuto do manual escolar, a das mudanças de responsabilidades que afetam a vida profissional do professor, e muitos outros.

\section{Cada TIC no seu lugar}

A tecnologia não é um valor absoluto, de uso universal. Pelo contrário, o seu emprego deve ser específico, pelo menos em relação ao tipo de disciplina em questão. Consideremos os dois principais grupos de disciplinas: aquelas em que predomina a aquisição de conteúdos, e as que privilegiam a aquisição de competências ou habilidades ${ }^{8}$.

No primeiro grupo colocamos matérias como a biologia, a história, a geografia, a física, as tecnologias, as ciências econômicas. Esta categoria tem por finalidade a aquisição de saberes articulados uns com os outros, que se adicionam de maneira linear (Dieuzeide,1994. p.151).

O segundo grupo compõe-se de matérias como a matemática, o português, as línguas vivas, a educação artística, a educação física. Esta categoria tem por finalidade

\footnotetext{
${ }^{8}$ Esta divisão é arbitrária de um ponto de vista transdisciplinar, mas é operatória na medida em que se considera que a transdisciplinaridade não tem por vocação suprimir as disciplinas. Numa ótica psicopedagógica, a distinção faz-se necessária.
} 
contribuir para a aquisição de mecanismos intelectuais, comportamentais, instrumentais para a resolução de problemas, incluindo-se aqui o problema da aprendizagem das disciplinas "de conteúdos", 9

As NTCIs intervêm de maneira diferente em cada uma dessas categorias. Por exemplo: para o aluno do primeiro grupo o que importa são os auxílios para classificar e organizar os conhecimentos que lhe chegam por todos os meios; o papel das TICs é interessante uma vez que elas oferecem recursos eficientes nesse sentido.

No ensino primário o aluno tem de adquirir, simultaneamente, mecanismos fundamentais de ordem sociocognitiva, competências globais (por exemplo a aprendizagem da leitura e a prática da expressão escrita), saberes disciplinares, aptidões para descrever, comparar, compreender... Constata-se que, para cada uma dessas funções, o leque de escolha de auxiliares técnicos é muito aberto. Um documento audiovisual pode intervir eficientemente em aulas de geografia, de história, de ciências.

No ensino secundário, e particularmente nas disciplinas da primeira categoria, os auxiliares técnicos desempenham papéis diferentes e complementares:

- as telecomunicações favorecem o acesso e a coleta de informações em bancos de dados;

- o audiovisual favorece a apresentação explicativa/ilustrativa do real;

- a informática favorece a classificação, hierarquização dos dados coletados e a criação de situações de simulação.

\footnotetext{
${ }^{9}$ Em muitas faculdades de educação existem ainda departamentos de "métodos e técnicas" de educação, cuja missão é precisamente possibilitar aos professores a aquisição de competências técnicas, aplicáveis numa multiplicidade de disciplinas.
} 
Nas disciplinas da segunda categoria (as que privilegiam a aquisição de competências), os auxiliares técnicos contribuem diferentemente:

- o multimeio interativo, nos treinos e exercícios de manipulação e de invenção, bem como na simulação;

- o audiovisual, na análise crítica das representações do real;

- as telecomunicações, na formulação, teste e intercâmbio de hipóteses e informações.

Existem quadros e esquemas variados que dão conta das teorias expostas acima. O que se nota, entretanto, é que um erro de escolha tem conseqüências mais graves no setor da educação do que em outros setores sociais, inclusive no da comunicação.

\section{O paradigma informático}

Não se adquire uma verdadeira cultura instrumental sem recorrer à história das técnicas e sem analisar as suas potencialidades pedagógicas. Essas precauções são determinantes para a credibilidade do professor junto aos alunos. Elas se constituem, além disso, uma condição indispensável para proporcionar a segurança e a eficiência no trabalho. Um pouco de cultura tecnológica permite evitar erros de consequiências imprevisíveis.

A informática é um bom modelo neste sentido. Observemos, por exemplo, como um simples estudo de suas dinâmicas de difusão social permitirá uma melhoria sensível nos critérios de escolha pelo professor.

Ele constatará que, como todas as outras técnicas, a difusão maciça da informática, a partir dos anos oitenta, dependeu substancialmente das representações sociais dominantes. Sua entrada no sistema educacional dependeu, além disso, de fatores tais como a variedade e a pulverização das disciplinas, a massificação do ensino, a fixação de novos objetivos macrossociais para a educação, os estatutos particulares dos atores 
(docentes, administradores, alunos e o próprio corpo social), a formação recebida pelos docentes, o tipo de escola, a multiplicação de estatutos da escola, a privatização do ensino, a reforma das escolas de formação de professores, etc.

Cada um desses fatores representa um obstáculo para uma implantação adequada de uma técnica. A informática superou-os todos, tornando-se banal. Com isso, ganhou em popularidade e vai perdendo progressivamente o seu caráter de símbolo da inovação.

Os primeiros cursos escolares relativos à informática, durante os anos setenta, tiveram como objeto a própria informática. O computador era o conteúdo do ensino.

Essa situação evoluiu sensivelmente: os currículos integraram pouco a pouco os instrumentos aplicativos (softs) e foram abandonando proporcionalmente o interesse pela máquina em si. Contribuíram para esse movimento, uma certa simplificação das máquinas e a sua vulgarização devido ao aumento inversamente proporcional entre a quantidade de préstimos que oferece e os seus preços de venda. Hoje o ensino da informática pura está em vias de desaparecimento, sendo reservado quase exclusivamente às formações técnicas ligadas à industria de equipamentos e de programas. Seu deslocamento nas hierarquias curriculares acontece antes mesmo que ela tenha adquirido, na maioria das sociedades, o estatuto de "eletrodoméstico".

Enquanto isso, no seio da escola, a informática está mudando sensivelmente de função. Em lugar de constituir-se num sistema ameaçador, revela-se um excelente auxiliar do trabalho tradicional do docente. Não se presume, entretanto, que ela permanecerá como está; pelo contrário, sua interferência tende a expandir-se para setores cada vez mais amplos do sistema escolar, embora possa se considerar que a fase "revolucionária" esteja ultrapassada.

A banalização da informática tem também consequiências negativas. A situação de desigualdade ainda permanecerá por muito tempo, uma vez que nem sempre ela está ao alcance das escolas mais pobres. Constatou-se já na época da difusão maciça da 
televisão (nos anos sessenta e setenta) que a banalização simbólica de uma tecnologia não implicava automaticamente a solução dos problemas gerais de desenvolvimento. Com a informática, há um risco de retrocesso, não ao período pré-informático dos anos ciqüenta e sessenta, mas ao século XVIII, em que, na ausência de um Estado democrático, as associações caritativas assumiam a grande parte do ensino das camadas mais pobres da população. Hoje é o setor privado que ocupa o espaço vazio. As escolas caritativas desapareceram e o Estado, mesmo quando democrático, não pode sozinho suportar a totalidade da carga educacional. Na ausência de soluções novas, alarga-se o fosso entre escolas ricas e escolas pobres.

Soluções novas são tentadas em muitos países. Todas se fundamentam na extrema adaptabilidade das NTCIs, mas uma entre elas pode servir-lhes de paradigma: é a informática, que cristaliza sozinha as esperanças no fim da contradição existente entre um Estado liberal não intervencionista e uma empresa privada centrada necessariamente na "obtenção de lucro".

Propomos aqui um inventário desse "paradigma". Existem muitos outros, mas não se pode tratar de todos neste trabalho. Por exempo, o paradigma editorial pelo qual poderíamos abordar as mudanças nas noções de programa, de difusão, ou de manual escolar. $\mathrm{O}$ modelo informático apresenta a vantagem de reunir, tanto no contexto educacional como nos outros, a maioria dos elementos que permitem pensar as inovações técnicas recentes e as mutações sociais por elas produzidas. Ma, antes, cabe lembrar que, se as potencialidades do paradigma informático são reais, é ainda cedo demais para depositar nele todas as esperanças de resolução dos problemas educacionais.

a. A informática tem a virtude de se adaptar a todas as diciplinas, inclusive àquelas que, aparentemente, deviam ficar distantes dela porque são fundadas na lógica analógica, em particular no modelo da escritura gutemberguiana. É o caso das disciplinas literárias, como a lingüística. Mas, paradoxalmente, a linguística foi uma 
das primeiras ciências a investir-se da informática. A prolongada sobrevivência do estruturalismo em literatura deve-se em boa parte ao desenvolvimento das técnicas de análise numérica da língua. Essa incorporação opera hoje em setores industrializados de tratamento automático das línguas, de comando vocal, de tradução automática, de transcrição automatizada de escrituras alfabéticas. É claro que nas disciplinas ditas “digitais", ligadas às chamadas ciências "exatas", a informática tornou-se "ferramenta" indispensável.

b. Enquanto os recursos audiovisuais utilizados como suportes educativos, assumiram desde o início uma forte conotação cultural, estética e ilustrativa, a informática, ao contrário, apareceu imediatamente como um recurso científico. Só mais tarde ela desenvolveu aplicações propriamente estéticas. Mesmo os primeiros softs de composição musical apareceram como objetos "científicos" Essa conotação contribuiu para dar à informática um alto grau de credibilidade na pedagogia.

c. A informática transformou o estatuto do aluno: de consumidor de saberes ele passou a ser, também, autor. Sabemos que esse argumento é frágil, pois se assenta tanto na realidade empírica quanto numa realidade imaginária, que não excluem a dimensão do marketing. Não se pode ocultar entretanto o fato de que o aluno pode criar, como o professor, certos elementos de aprendizagem, e, nesse ponto, a informática cumpre um dos desafios já antigos da educação que é o da participação ativa do aluno no ato de aprender.

d. A informática possui uma dimensão interativa nem sempre presente nas outras tecnologias educacionais. $\mathrm{O}$ aluno intercambia com a máquina séries mais ou menos longas e complexas de informações, e isso numa confrontação pessoal simultaneamente exploratória e lúdica. A interatividade e a hipertextualidade, que permitem ao aluno manipular indefinidamente textos e imagens, montar e desmontar as formas e conteúdos dos objetos simbólicos do conhecimento, abrem-lhe portas que antes só eram abertas aos alunos mais motivados das escolas bem-dotadas, alunos 
vivendo em contextos favoráveis e ajudados por docentes de grande qualidade, de boa formação humanística e disciplinar.

A interatividade tem uma conseqüência importante no processo geral de aprendizagem: nas formas tradicionais de educação o aluno é levado a progredir de maneira linear, passo a passo, numa ordenação curricular que supõe que não haverá vazios na sua formação se ele obedecer ao currículo "oficial". Na informática, a progressão na aprendizagem pode ser rompida pelo professor ou pelo próprio aluno, por escolhas que eles podem operar em cada seqüência interativa.

Como ocorre na educação tradicional a interatividade contém uma dimensão ilusória: ela nunca vai além de um certo limite, que o aluno atinge relativamente de modo rápido. Esse handicap vai sendo superado na medida em que a potência de cálculo das máquinas aumenta e em que os softs se complexificam. Assim está aberta a concorrência entre a inteligência artificial e a inteligência natural; todo prognóstico sobre os resultados é ainda pura ficção.

e. A informática permite desenvolver competências e atos concretos de auto-avaliação, outro compromisso antigo da pedagogia ativa. O ponto fraco da avaliação tradicional é a confrontação do aluno com a sua própria imagem: gratificações ou punições põem em risco seus equilíbrios vitais; a desagregação da personalidade nunca está longe nesse caso. Com a máquina, a auto-avaliação assume outros contornos: o "outro" julgador não tem juízo, só apresenta reações e cálculos totalmente indiferentes a qualquer emoção ou postura ética. Os programadores de softs pedagógicos incluem até dimensões de estímulos nos protocolos de auto-avaliação cujas virtudes, pouco estudadas ainda, podem contribuir para o aumento da motivação de aprender.

Pela interatividade, o computador ajuda a expressão individual sem contestação nem castigo; o princípio de estímulo e de prazer dominam sem suprimir totalmente o princípio de esforço da aprendizagem. 
É necessário lembrar, a propósito da avaliação, os limites que a explosão informática apresenta em todos os setores, desde os de dimensão puramente fisiológica como a fadiga ocular, até os de dimensão ética, cognitiva, estética, filosófica, ideológica. Cada um no seu âmbito é tão respeitável quanto o outro, mas nenhum pode suprimir a dimensão empírica. O problema do educador, entretanto, não parece ser o da multiplicidade de aspectos da relação entre educação e tecnologias, mas o fato de ter de pensá-los juntos a fim de não alienar os benefícios da ação aducativa.

f. A construção do raciocínio já não é linear, mas torna-se multidimensional: parar num ponto dado do raciocínio e escolher premissas ou alternativas diversificadas, conduz à formação do julgamento e de novas competências cognitivas centradas na variedade. Maior abertura e tolerância aos outros são corolários. A informática tem um caráter mais dinâmico do que a maioria dos outros suportes técnicos.

g. Como ocorreu com a fotografia e a televisão, em poucos anos o uso da informática expandiu-se, do campo profissional ao campo pessoal. Este fator é de extrema importância para os docentes e para os alunos: o domínio da técnica acaba por ser desmistificado, simplificado. É mais uma barreira que cai entre as duas instâncias. Metaforicamente a aprendizagem da escrita alfabética operava da mesma maneira. A facilidade de transferência dos usos pessoais aos usos profissionais, dos usos lúdicos aos pedagógicos faz com que docentes e alunos disponham de duas motivações fortes em vez de uma só.

h. Enfim, coloca-se a questão de saber o que se produz com a informática. Nós vamos reduzir a esfera dessa questão ao denominador mais simples, mas também mais fundamental, o da sua eficiência no processo de aquisição dos mecanismos fundamentais da aprendizagem, destino final de toda atividade pedagógica, e, de certa maneira, bem mais importante do que a mera aquisição de conteúdos. Constata-se neste ponto que a informática permite ao aluno (sem falar do professor) adquirir, quase inconscientemente, um dos mecanismos-chave da aprendizagem que consiste, no nível 
cognitivo, em integrar, ao processo pedagógico, a dimensão analítica e sintética ao mesmo tempo. Produz-se de uma certa maneira a reconciliação entre as potencialidades próprias do hemisfério direito e do hemisfério esquerdo, ou seja: do analógico e do numérico.

\section{TRANSIÇÃO PARA O FUTURO}

\section{O período atual: síndrome da transição permanente}

O período atual caracteriza-se por um sentimento de interminável transição. Admite-se que há pouca coisa de fundamentalmente original nas novas tecnologias e, ao mesmo tempo, que a abundância de novidades técnicas transforma o mundo. Entre o enfoque do historiador e o do sociólogo da contemporaneidade, entre a filosofia e a economia, entre a cultura e a tecnologia deve existir um ponto de vista que satisfaça o pedagogo. Toda a dificuldade está em decidir qual será o enfoque capaz de equacionar a realidade empírica e a ação que ela solicita.

Esse "ponto de vista" talvez possa ser encontrado considerando-se as tecnologias atuais simultaneamente como "continuidades" das tecnologias precedentes e como rupturas em relação ao passado. A partir disso é possível ter melhores condições para observar os movimentos que operam nas camadas invisíveis do sistema social. Da mesma forma, pode-se ter maior capacidade para julgar e operar escolhas que envolvam o sistema educativo. Tomemos como exemplo a evolução do telefone.

Pode-se considerar que o telefone celular é o filho direto do telégrafo ótico de Chappe, criado em 1790 como arma de guerra pela Convenção Revolucionária e como instrumento político de unificação do Estado Francês (Flichy, 1997). Mas pode-se também considerar que o mesmo telefone de hoje, que liga um usuário com o mundo inteiro via um satélite com uma pilha de 4 volts, não tem nada em comum nem com o ótico de Chappe nem com o elétrico de Edison. Considerado como uma 
"paleotécnica" ao lado do rádio, do cinema ou da fotografia, o telefone não é ainda uma tecnologia estável e presume-se que não o será tão cedo. Observe-se, no quadro abaixo, a exuberante filiação do telégrafo! A mesma coisa acontece com todas as tecnologias de que se serve o cidadão em geral e o professor em particular.

\section{QUADRO 2}

\section{FILIAÇÃO TECNOLÓGICA DO TELÉGRAFO}

\begin{tabular}{|c|c|c|c|c|c|c|c|}
\hline 1847 & 1877 & 1920 & 1930 & 1960 & 1975 & 1984 & 2000 \\
\hline Telégrafo & $\begin{array}{l}\text { Telégrafo } \\
\text { Telefone }\end{array}$ & $\begin{array}{l}\text { Telégrafo } \\
\text { Telefone } \\
\text { Som }\end{array}$ & $\begin{array}{l}\text { Telégrafo } \\
\text { Telex } \\
\text { Fac-símile } \\
\text { Telefone } \\
\text { Som } \\
\text { Televisão }\end{array}$ & $\begin{array}{l}\text { Telégrafo } \\
\text { Telex } \\
\text { Dados } \\
\text { Fac-símile } \\
\text { Telefax } \\
\text { Telefone } \\
\text { Som } \\
\text { HF/estéreo } \\
\text { Televisão } \\
\text { em cores } \\
\text { Telefone } \\
\text { móvel }\end{array}$ & $\begin{array}{l}\text { Telégrafo } \\
\text { Telex } \\
\text { Dados } \\
\text { débito médio } \\
\text { Dados baixo } \\
\text { débito } \\
\text { Fac-símile } \\
\text { Telefax } \\
\text { Telefone } \\
\text { Televisão } \\
\text { em cores } \\
\text { Som } \\
\text { HF/estéreo } \\
\text { Telefone móvel } \\
\text { Chamada à } \\
\text { pessoa (pager) }\end{array}$ & $\begin{array}{l}\text { Telégrafo } \\
\text { Telex } \\
\text { Dados } \\
\text { comutados por } \\
\text { pacotes (tradu- } \\
\text { ção confirmada) } \\
\text { Dados alto } \\
\text { débito } \\
\text { Dados } \\
\text { comutados } \\
\text { por circuitos } \\
\text { tradução con- } \\
\text { firmada) } \\
\text { Telemedida } \\
\text { Fac-símile } \\
\text { Teletexto } \\
\text { Telefax } \\
\text { Videotexto } \\
\text { Telefone } \\
\text { Videoconferên- } \\
\text { cia } \\
\text { Som HF/estéreo } \\
\text { Televisão } \\
\text { em cores } \\
\text { Televisão em } \\
\text { estereofonia } \\
\text { Telefone móvel } \\
\text { Chamada à } \\
\text { pessoa (pager) }\end{array}$ & $\begin{array}{l}\text { Telégrafo } \\
\text { Telex } \\
\text { Dados em banda } \\
\text { larga (tradução } \\
\text { confirmada) } \\
\text { Dados comutados } \\
\text { por pacotes (tradu- } \\
\text { ção confirmada) } \\
\text { Dados comutados } \\
\text { por circuitos } \\
\text { (tradução confir- } \\
\text { mada) } \\
\text { Telemedida } \\
\text { Teletexto } \\
\text { Texto por Telefax } \\
\text { Telefax } \\
\text { Telefax em cores } \\
\text { Correio eletrônico } \\
\text { Teleimpressão de } \\
\text { jornais } \\
\text { Videotexto } \\
\text { Telefax vocal } \\
\text { Telefone } \\
\text { Telefone alta } \\
\text { fidelidade } \\
\text { Telerreunião } \\
\text { Videoconferência } \\
\text { Videofonia } \\
\text { Som alta } \\
\text { fidelidade estéreo } \\
\text { Quadrifonia } \\
\text { Televisão em } \\
\text { cores } \\
\text { Televisão em } \\
\text { estereofonia } \\
\text { Televisão alta } \\
\text { definição } \\
\text { Visiofone móvel } \\
\text { Telefone móvel } \\
\text { Texto móvel } \\
\text { Telefax móvel } \\
\text { Dados móveis } \\
\text { Videotexto móvel } \\
\text { Chamada à pessoa } \\
\text { (pager) }\end{array}$ \\
\hline
\end{tabular}

Fonte: Adaptação de Ungerer, Costello, 1990. 
Quatro anos antes de 2000 quase todas as previsões deste quadro, feitas em 1988, estavam no mercado, inclusive no mercado doméstico ${ }^{10}$. A televisão de alta definição -televisão digital -- oferece num só feixe 175 canais (é o caso do grupo Direct TV), com capacidade para direcionar com precisão o feixe de difusão, o que permite, por exemplo, “evitar a deserção das arquibancadas dos estádios”, por uma delimitação precisa das zonas de cobertura, o que permite a uma estação de televisão difundir uma partida de futebol para todo o Brasil, e ocultar, ao mesmo tempo, o território da cidade onde acontece o evento. O sistema, ainda muito oneroso, permite preservar o mercado de venda de ingressos para o clube e o de venda publicitária para a estação de televisão (Rouy, 1996).

Nessas condições não é prova de irracionalidade considerar a maior parte das técnicas atuais como imaturas, porque em contínua evolução e, além disso, caras, sujeitas a fortes reticências de apropriação simbólica, complexas na apropriação prática. Apesar desses handicaps, elas se expandem por todos os espaços públicos e privados. Como explicar essa força aparentemente incontrolável das tecnologias?

\section{A industrialização da educação}

Não há espaço aqui para dar uma resposta minuciosa à pergunta feita acima, mas já temos notado que, mesmo sem aderir, pode-se pelo menos compreender a vitalidade contemporânea da técnica em geral e das técnicas educacionais em particular. Todas as razões que dão suporte a essa atitude (mental, não normativa) baseiam-se na existência de usuários do mercado aberto, semelhantes a consumidores, e não mais a públicos cativos do sistema escolar tradicional.

Os usuários não podem, de fato, ficar indiferentes à evolução técnica: ela se veste com todas as virtudes do progresso e da melhoria (ao menos simbólica) do nível de vida.

10 Em 1995, nove milhões de lares norte-americanos possuíam a última dessas técnicas, a Internet; eles serão mais de 25 milhões no ano 2000, o que representa um terço dos lares do país. 
A demanda técnica, real ou suposta, está por sua vez ancorada numa forte vontade dos Estados que descobriram nela o melhor fator estruturante das sociedades modernas. Ela permite aos poderes políticos, econômicos e culturais o exercício do controle social em níveis planetários, num movimento muito similar ao do livro da Idade Média mas com uma potência espaço-temporal incomparavelmente maior. Para legitimar esse sistema os poderes instituídos se servem, como em outros tempos, dos mesmos discursos que apresentam a tecnologia como a panacéia para todos os déficits sociais, incluídos os da educação. É assim que o sistema econômico deslocou seus investimentos dos setores de bens materiais para os setores de bens imateriais, precisamente onde opera o sistema educacional.

A conjunção de uma demanda por melhores condições de vida, por novas formas de exercício da cidadania, e o deslocamento da rentabilidade dos investimentos industriais produziu o que Abraham Moles (1986) chamou “'abundância comunicacional”.

O professor, que já vive situações deprimentes no exercício de sua profissão (pobreza endêmica da escola, fragilidade aparente dos resultados em termos de inserção social e profissional dos alunos, fragilidade do reconhecimento coletivo etc.) deve agora também enfrentar a concorrência da técnica e de seu sistema de produção. Aderir ou desaparecer, passando do estatuto de transmissor de conhecimentos ao de produtor de produtos. Não um produtor protegido, como dantes, por um sistema refratário a toda avaliação ou sanção, mas um produtor em esquema industrial, em competição com outros produtores que não subscrevem o mesmo contrato moral da corporação educativa. Mergulhado num sistema de concorrência, o docente se obriga a substituir a prova da competência pedagógica e das antigas legitimidades sociais pela prova da rentabilidade econômica.

Convidados com muita insistência a entrar nesse mundo que promete ao mesmo tempo sucesso, reconhecimento e abundância, não é estranho constatar que muitos profissionais da educação desanimem em meio a sentimentos confusos de 
manipulação, de perda das finalidades do seu trabalho, de síndromes da inutilidade social. Fechados no recinto da escola, muitas vezes eles tendem a proteger-se da competição com os "novos educadores" externos ao sistema.

Essa é outra consequiência da industrialização da educação: não são só os "produtos" que mudam, mas também os "produtores". As empresas investem na educação exatamente da mesma maneira que investem em comunicação, em seguros, em tratamento de águas.

Como os outros setores industriais, os da educação -- produtos e atores juntos -- devem estar orientados para as massas, ser rentáveis, submissos às leis da economia (série, escala, qualidade de massa, repetição, difusão capilar, etc.), ou seja, qualidades consideradas secundárias, imorais ou simplesmente incongruentes no sistema de educação tradicional.

Há pois combinação de dois sistemas que parecem completamente antagônicos: um em que o tempo é longo, o da educação, com outro, econômico, em que o tempo é curto; um em que o benefício é primeiramente simbólico - da ordem do saber e das representações - e o outro em que o benefício é material; um em que o produto é um simples suporte do saber, um vetor, o outro em que o produto é o objetivo final pois que ele contém o valor de troca financeira.

A orientação da educação dentro da lógica econômica tem, entretanto, seu aspecto positivo. Já vimos, por exemplo, que ela alargou consideravelmente o público da escola, acelerou a inclusão do público adulto, incorporou o público distante pelo ensino a distância, e, por sua vez, se enriqueceu com a legitimidade social recebida pelos seus suportes técnicos, eles próprios socialmente legitimados na sua passagem de iniciação pelo sistema educacional.

Deve-se, entretanto, levantar a hipótese de que os benefícios da industrialização da educação, como os da informática, não são devidos unicamente a fatores econômicos. 
A difusão do cinema, do rádio educativo, ou ainda, anteriormente, a introdução da imagem na sala de aula no final do século passado, toda mutação técnica é o resultado de combinatórias complexas em que se misturam elementos políticos, financeiros, técnicos e sociais. Quando esses elementos convergem, ao mesmo tempo e num mesmo lugar, então há inovação.

A imprensa também nasceu num contexto deste tipo. Ela capitalizou toda a "ecologia técnica" do seu tempo: o primeiro livro impresso, o Psaltério de Maiença, em 1457, nasceu porque Johannes Gutemberg vivia entre cunhadores de moedas que conheciam perfeitamente as técnicas de aliagem de metais, dos papéis e das tintas de impressão. Deve-se acrescentar que esses artesãos conheciam também as técnicas de comércio e de lucro; assim, o livro nasceu como um instrumento de comunicação e, simultaneamente, como um produto comercial. Esses dados, mais a convergência do movimento de renascimento intelectual fizeram com que se tornasse a primeira grande indústria tayloriana e comercial moderna: entre 1457 e 1500, foram fabricados entre 15 e 20 milhões de livros distribuídos em 35 mil edições, o que equivale a uma produção média na Europa de 1300 livros por dia (Breton, Proulx, 1991. p. 44).

\section{Novas desigualdades}

Legitimidade social, mercadoria, bem de troca... os novos produtos tecnológicos na realidade não são os primeiros a terem esse estatuto. Só que os precedentes, inclusive o livro, sobreviviam dentro de esferas de difusão e de uso direto extremamente reduzidas e beneficiavam a números igualmente reduzidos de aprendizes. Até o audiovisual pedagógico dos anos recentes não gozou de uma difusão maciça na escola, apesar de existirem (quase) todas as condições para isso. $\mathrm{Na}$ realidade os custos muito altos dessas tecnologias (em média 10 mil reais para dez minutos de vídeo de qualidade aceitável) fazem com que nenhum sistema educativo possa garantir-lhes um uso maciço. Esse custo é equivalente ao do filme comercial e, em dez minutos, ele consome o que o Estado francês investe em três estudantes do ensino superior durante 
um ano inteiro. Qual Estado moderno pode nessas condições garantir sozinho uma educação de boa qualidade para todos os cidadãos?

Não há uma causalidade direta entre a capacidade da indústria para produzir produtos educativos e a capacidade da sociedade para satisfazer às necessidades educativas e culturais de toda a população. Se tal fosse o caso teríamos ali, em meio às convulsões constantes do sistema educacional, a solução para questões bem antigas como a educação de todos os cidadãos, a noção de público educativo recobrindo totalmente a noção de público em geral, o espaço da escola se alargando para a esfera doméstica, para o trabalho e outros espaços públicos.

Essa utopia também não é moderna. Apesar de suas novas e imponentes dimensões, a massificação da educação não representa ainda uma garantia suficiente de que agora as massas vão ser educadas rápida e eficientemente e, ainda menos, de que as funções sociais da escola vão enfim estar clarificadas. Acontece que não basta romper os muros e massificar os produtos educativos. É necessário, além disso, que as massas tenham acesso real e permanente a eles. Ora, a evolução econômica e social das massas não significa o seu acesso automático aos bens tecnológicos. Por um lado, porque há discronia entre desenvolvimento social e desenvolvimento tecnológico, e, por outro, porque a apropriação operacional em termos culturais da tecnologia supõe, ela mesma, que haja formação (portanto educação na base) e produtos adequados.

Conclui-se que a massa que tem acesso aos produtos educativos das NTCIs não é diferente da massa que compra uma geladeira, uma televisão ou comida cada dia; que um produto, para ser comprado deve ser comprável, e ele o é somente quando há poder aquisitivo no meio social. Essas banalidades econômicas significam que os excluídos da educação serão os mesmos excluídos do circuito de consumo e do bem estar social. Os "antigos" excluídos da escola tradicional, são, globalmente, os mesmos excluídos da escola transformada em mercado aberto, regida pelas leis da economia e pelas NTCIs. 


\section{NOVAS PERSPECTIVAS}

$\mathrm{O}$ futuro de meio e longo prazo está sujeito a expectativas semelhantes às que precederam as grandes mutações tecnológicas deste século -- panacéias, messianismo, utopias. Difícil de antecipar enquanto não se estabilizarem as tecnologias e o processo de mundialização econômica. Pode-se, entretanto, tentar algumas previsões de evolução.

\section{Mudança do estatuto do professor}

O deslocamento generalizado dos produtos pedagógicos da escola para a indústria e para a massa que pode pagar induzirá uma perda de poder dos atores tradicionais da escola: eles já não serão os interventores privilegiados, legitimados, da educação (com seus cursos presenciais, suportes ilustrativos, apostilas, livros, giz, quadro-negro e até o computador), já não terão o mesmo controle sobre o processo de aprendizagem e, menos ainda, sobre o sistema educacional como um todo. Ou melhor, o seu controle poderá limitar-se ao acompanhamento do aluno, não um acompanhamento eufemístico ou metafórico como "os acompanhantes dos alunos no caminho do saber", mas de um acompanhamento em sentido próprio, isto é, estar ao lado do aluno para sustentar seus esforços pessoais e ajudá-lo a transportar a mochila. Para os mais pessimistas, o professor será o acompanhante dos alunos no supermercado do conhecimento.

Além disso, o professor, que nunca foi o detentor exclusivo do saber, passa a ser ainda menos agora: a indústria "serve-se" dele como de um recurso entre outros; o professor como prestatário da indústria pedagógica.

Mas o papel de prestatário também se desloca para o de conselheiro e perito, com poucas vantagens sobre os outros conselheiros e peritos free lancer do mercado, profissionais que não são nem necessitam ser professores titulares. Um especialista instalado na cidade ou no campo e munido de equipamentos de conexão a bases multimeios espalhadas pelo mundo, tem em mãos recursos que nenhum sábio do 
passado teria ousado imaginar: acesso a fontes bibliográficas, bases de dados, museus, centros de pesquisa, a partir dos quais formula protocolos de associação de conteúdos, produz informações pedagógicas, manuais, suportes hipertextuais interativos, dá indicações estratégicas aos editores e industriais e, enfim, acaba exercendo o ofício de professor mesmo que as semelhanças pareçam longínquas.

Os produtos que decorrem dessas novas profissões e organizações educacionais entram na categoria dos objetos de marketing publicitário, banalizados no mesmo nível das outras categorias de produtos. Leia-se, por exemplo, a esse respeito, os catálogos dos grandes grupos editoriais como Hachette ou Abril, e lá se encontrarão, misturados, manuais de geografia, vídeos, CDRoms, CDs, revistas em geral, endereços de bases na Internet, eles mesmos operados por produtores que têm, nos seus grupos, aviões, livros, equipes esportivas e fábricas de roupas.

\section{Integração mundial da educação}

Enquanto ousamos apenas entrar nessa nova educação, assentada em produtos, em última análise, viáveis economicamente e eficientes do ponto de vista educacional, já estamos, de fato, numa era nova, dominada pela integração das redes mundiais de dados. Atualmente, como vimos, essa integração já existe e se alimenta em grande parte do mercado educacional. Mas a rede atual está fundada numa lógica pesada, custosa, que obriga, por exemplo, cada sala de aula a equipar-se com materiais pouco confortáveis, caso deseje ter acesso a documentos distantes, mais ou menos como ocorreu com a televisão educativa de algumas universidades brasileiras dos anos setenta, que, após alguns anos de serviços caóticos, caiu em desuso.

A evolução atual das redes integradas deverá suprimir esses equipamentos: computadores sofisticados, provedores caros, bases próprias, infraestrutura de cabos etc. 
O conhecimento não estará mais estocado em produtos como CDRoms e discos winchesters pesados e caros. Toda a informação estará concentrada numa miríade de lugares fixos em que os navegantes das redes mundiais irão, com certeza, “estudar'. Essas fontes já representam hoje um potencial sem comparação com os recursos das melhores escolas do mundo.

Por que estocar no seu winchester as obras completas de Sheakespeare se você pode aceder a elas facilemente e em qualquer lugar do mundo ? [ pergunta Bernard Benhamou ]. Por que pagar caro os CDRoms quando será possível conectar-se a todas as escolas ou universidades e obter toda a informação que nenhuma coleção de filmes pedagógicos dos anos 60-80 era capaz de oferecer? Essas máquinas "não PC', sem winchester, sem disquete, um modem, pouca memória, um chip, o conjunto custando menos de 500 reais [e por que não alugar?], são o símbolo de uma sociedade em que a riqueza mais importante será a informação e não as máquinas [o contéudo e não o suporte]. (Benhamou, 1996. p.62)

É claro que tais perspectivas conduzem a mudanças equivalentes de atitudes em relação às máquinas, quer sejam elas um computador ou um televisor.

\section{Ubiqüidade e gratuidade}

Para o filósofo Michel Serres vão ocorrer duas outras mutações importantes. Ele diz:

No sentido etimológico, a pedagogia significa a viagem da criança em direção às fontes do saber. Até então existiam lugares de saber, um campus, uma biblioteca, um laboratório, por exemplo. Com os novos meios, é o saber que viaja. E essa inversão transforma completamente a idéia de classe ou de campos: a concentração do saber vair explodir. A rede torna possível, simultaneamente, a difusão do saber e o aparecimento de novas fontes. Tudo isso se fará sob a pressão da economia porque os lugares de concentração do saber, como a universidade, serão cada vez mais caros. (Serres, 1996. p.28-30)

' 'O que aparece com a Internet é também a noção de gratuidade do saber', continua Michel Serres. Assim, vamos passar de uma sociedade de comunicação a uma sociedade de pedagogia, em que o saber será gratuito e, uma vez difundido, não terá mais proprietário. As relações entre mestre e aluno se transformarão em razão disso, 
serão de natureza mais horizontal e sem lugar fixo; um aluno pode estar em Londrina, outro em Belo Horizonte, em Santiago do Chile e outro, na rua vizinha. "Sobre a noção de gratuidade do saber, vale lembrar que, nem sempre, aquele que pode comprar um CDRom tem tempo para estudá-lo e, às vezes, aquele que tem tempo não pode comprá-lo".

Eis-nos aí no ponto de chegada do circuito: as evoluções tecnológicas atuais que integram o setor educacional, como as do passado, acabam por transformá-lo. Sobre esse ponto há poucas dúvidas, e supõe-se que a mutação será, desta vez, extremamente profunda, tendo como saldo inquietações sociais tão grandes quanto as esperanças que ela suscita. Tomar consciência dessas mutações e das suas conseqüências constitui um desafio mais importante para professores e comunicadores do que o foi a lenta e caótica apropriação das novas TICs dos anos trinta para cá.

Para os intelectuais como para os atores da vida educacional em geral, a história das relações entre comunicação e educação deixa algumas lições interessantes. A primeira, entre elas, é a constatação de que as Novas Tecnologias de Comunicação e de Informação não provocaram a série de pragas anunciadas como decorrentes de sua implantação social. Claro que não se dispõe ainda de todos os dados para analisar eficientemente os efeitos das NTCIs na educação, mas, no mínimo, deve-se constatar que elas não provocaram rupturas regressivas irreparáveis nos sistemas sociopolíticos nem nas suas práticas educacionais cotidianas.

Pensou-se que a explosão da informática suprimiria milhões de empregos; mas nos países em que há desemprego maciço, não se pode atribuí-lo somente à informática.

Supôs-se também que ela reduziria consideravelmente o número de professores, quem sabe mesmo extinguiria essa profissão; na realidade todas as sociedades desenvolvidas e em desenvolvimento, mesmo as que dispõem de sistemas educacionais altamente informatizados, nunca precisaram tanto de professores como hoje. 
Além disso, a informática provocou necessidades novas e especialidades novas que vêm enriquecer o trabalho dos professores e do sistema educacional como um todo. Uma dessas novas profissões é, por exemplo, o engenheiro pedagógico, personagem indispensável que vem inserir-se entre o professor e os conteúdos e entre os conteúdos e os alunos. Nos sistemas pré-informáticos o professor é autor, "editor" e transmissor integral dos seus cursos; hoje, é impossível para ele dominar a totalidade do circuito.

Temia-se também pelo livro, pela leitura, pela escrita... As NTCIs não eliminaram nenhum deles. Modificaram certamente alguns dos seus dados, mas não provocaram a analfabetização geral que elas pareciam conter nas suas entranhas. Nesse caso, também houve fenômenos extraordinários de reforço de certos mediadores pedagógico-culturais precedentes tais como a leitura.

O que teria sido a História se os professores da Idade Média tivessem recusado o livro impresso sob o pretexto, por exemplo, de que o livro manuscrito mantinha o equilíbrio social da época, e que o livro impresso os ameaçava? Será que a mesma pergunta feita hoje em relação às NTCIs teria sentido?

\section{REFERÊNCIAS BIBLIOGRÁFICAS}

ACM Computing surveys. New York, v.29, n.4, Dec. 1997.

ANDREW W. MELLON FOUNDATION. Scholarly communication and technology. Washington, 1997. [Papers from the Conference Organized by AMF, Emory University, 24-25 abr. 1997.]

BARBIER, F., BERTHO-LAVENIR, C. Histoire des médias: de Diderot à l'Internet. Paris: Armand Colin, 1996. 352p.

BARON, G.L., BRUILLARD, E. L'Informatique et ses usages dans l'enseignement. Paris: PUF; Coll. L’Educateur, 1996. 320p. 
BARON, P., PAOLETTI, F., RAYNAUD, R. (org.). Informatique, communication et société. Paris: l'Harmattan/INRP, 1993.214p.

BASARAB, N. Transdisciplinarité cherche disciples. Le Monde de l'Éducation, Paris, n.252, p.48-9, 1997.

BAUTIER, R. De la rhétorique à la communication. Grenoble: PUG, 1994. 320p.

BENHAMOU, B. Bientôt le stade terminal. In: revista Télérama: le délire multimédia, n. Hors série, mai. 1996. p.62.

BIRDWISTELL, R. Human Communication theory: original essays. New York: Holt, Rinehort and Winston, 1967. In: Revue Sciences Humaines. Hors série, n.16, mar./avr.1997, p.20.

BLETTERIE, R. Quelles machines? Quel usage? Paris: Revue Pour, n.79, sept. 1981.

BOUNGE, G. de et al. Multimédia et enseignement supérieur. Paris: GO/ENST, 1996. $128 \mathrm{p}$.

BOURDIEU, P. Raisons pratiques: sur la théorie de l'action. Paris: Seuil, 1994. 251p.

BRETON, T. La dimension invisible: le défi du temps et de l'information. Paris: Odile Jacob-Points, 1994. 168p.

BRETON, P., PROULX, S. L'Explosion de la communication: la naissance d'une nouvelle idéologie. Paris; Montreal: La Découverte; Boréal, 1991. p.30-1.

BRINSON, P. Choice and care of films in fudamental education. Londres: The Olen Press for the Research and Publications Department of Film Centre Limited, 1950.

BUSATO, L. R. L'Empreinte des médias dans le langage des adolescents. Paris, 1982. Thèse (doct.) EHESS. 
. Lanterne magique: les voies de légitimation d'un objet technique. École de Hautes Études en Sciences Sociales: Paris, 1979.

CASSIRER, H. Brazil, educational television. UNESCO, 1967. Television: a world survey. UNESCO, 1952.

CHAPELAIN, B. Les vidéothèques d'établissement: étude de l'intégration et de l'útilisation de ressources audiovisuelles mises à la disposition des élèves et des enseignants dans l'établissement scolaire (collèges et lycées). Paris: INRP, 1996. $188 \mathrm{p}$.

CITElli, A. O. A Escola e os discursos não didáticos. Revista Comunicação $e$ Educação. São Paulo: Moderna; USP, n.8, p.27, jan./abr. 1997.

COHEN, R. (dir.) La Communication télématique internationale: des expériences à travers l'Europe. Paris: Retz, 1995. 256p. Coll. Pédagogie en Europe.

COMUNICAÇÃO E EDUCAÇÃO. São Paulo: Moderna; USP, n. 4-8.

COUlON, A. Ethnométhodologie et éducation. Paris: Puf, 1993. 238p. Coll. L'Éducateur.

CULTURE TECHNIQUE. Paris: Centre de Recherches sur la Culture Technique, n.2, avr. 1980.

DELMAS, R., MASSIT-FOLLEA, F. (dir.). Vers la société de l'information: savoirspratiques-médiations. In: Colloque du Comité National d’Évaluation. Actes du... Rennes: Apogée, 1995. 204p.

DELORS, J. L'Éducation: un trésor est caché dedans. Odile Jacob; UNESCO, 1996. 309p. [Rapport à l'Unesco de la Commission internationale sur l'éducation pour le vingtième-premier siède.] 
DIEUZEIDE, H. Les nouvelles technologies: outils d'enseignement. Paris: Nathan; Unesco, Paris, 1994. 247p. Coll. Les Repères pédagogiques.

DOSSIERS DE L'AUDIOVISUEL. Enseignement, formation et nouvelles technologies. Paris: Documentation Française, 1997.

EDUCATIONAL/INSTRUCTIONAL BROADCASTING: the international journal of educational Radio and Television. Los Angeles: v.1, n.3, jun./jul. 1968.

FICHEZ, E. (coord.) La Notion de bien éducatif: services de formation et industries culturelles. In: COLOQUE INTERNATIONAL DE LA SOCIÉTÉ FRANÇAISE DES SCIENCES DE L'INFORMATION ET DE LA COMMUNICATION. Roubaix, 14,15 janvier 1994. Actes du... IUP Lille-3, 1995.

FLICHY, P. Une histoire de la communication moderne: espace public et vie privée. Paris: La Découverte/Poche, 1997. 280p. Coll. Sciences humaines et sociales.

FRANKE, H.W. Kommunikations-medien und die zukunft der Hochschul-Ausbildung. Stuttgart: Deutsche Verlags-Anstalt GmbH, 1973. (Dokumentation zu linem Internationalen Symposium in Stuttgart, 2/4 Nov.1973.)

GERARD, A. Réseaux et multimédia dans l'éducation: Rapport au Premier Ministre, Paris: Ed. du Senat, 1997.

GIRARDOT, J.M. Radio en milieu scolaire et ... professionnalisme. Paris: MScope, 1993. (Dossier Nouvelles Technologies et Formation, 5.)

GLIKMAN, V., BARON, G.L. Technologies nouvelles et éducation: Quatre années de résultats de recherches à l'INRP (1991-1994). Paris: Institut National de la Recherche Pédagogique, 1995. 199p.

HYMES, D. La théorie de la communication humaine: essai original. Revue Sciences Humaines, Hors série, n.16, mar./avr. 1997. p.20. 
MARTIN-LALANDE, P. L'Internet: un vrai défi pour la France. Rapport au Premier Ministre. Paris, 1997.

MATTELART, A. La mondialisation de la communication. Paris: Puf; Que sais-je? 1996. 126p.

MIALARET, G., VIAL, J. (dir.). Histoire mondiale de l'éducation. Paris: Puf, 1981. $4 \mathrm{v}$.

MIÈGE, B. La société conquise par la communication - 2: la communication entre l'industrie et l'espace public. Grenoble: Pug, 1997. 216p.

MOEGLIN, P. Le satellite éducatif: média et expérimentation. Paris: Reseaux; Cnet, 1994.

MOLES, A. Théorie structurale de la communication et société. Paris: Masson; CENT/ENST, 1986. p.15.

MORALI, D., DAUVISIS, M.C., SICARD, D. Culture technique et formation. In: COLLOQUE DE L'ASSOCIATION DES ENSEIGNANTS CHERCHEURS EN SCIENCES DE L'EDUCATION. Nancy: PUN, 1995, 469p.

NAUDO, C. La Révolution informatique va-t-elle modifier l'enseignement? In: Revue Relations Écoles-Professions, n.68, mar-avr. 1996.

OSWALD, I. An Annotated bibliography on audiovisual instruction in professional education. New York: Council on Social Work Education, 1966.

PAPERT, S. L'Enfant et la machine à connaître: repenser l'école à l'ère de l'ordinateur. Paris: Dunod, 1994. 224p.

PRAKKE, H. Towards a philosophy of publicistics. Iowa: University of Iowa, Center for the Advanced Study of Communication, 1971. 
RAYNAL, F., RIEUNIER, A. Pédagogie: dictionnaire des concepts clés aprentissages, formation et psychologie cognitive. Paris: ESF, 1997. 405p.

ROUY, J. C. Le temps des "numérnautes". Paris: jornal Le Monde, suplemento Télévision-Radio-Multimédia, 22 avr. 1996.

SCIENCES HUMAINES. La comunication - état des savoirs. Especial, n.16, mar./avr. 1997.

SERRES, M. La concentration du savoir va être dynamitée. In: revue Télérama: Le délire multimédia, N. Hors Série, mai.1996. p.28-30.

SERUSCLAT, F. Apprentissage des nouvelles technologies de l'information. Paris: Ed. du Senat-Forum Internet, 1997. (Rapport de l'Office parlementaire d'évaluation des choix scientifiques et technologiques.)

SFEZ, L., COUTLEE, G., MUSSO, P. Technologies et symboliques de la communication: colloque de Cerisy. Grenoble: PUG, 1990. 432p.

TEKHNÉ/MÉDIAMÉTRIE. Médias: le livre des livres. Paris: Tekhné/Médiamétrie, 1996. 182p.

TÉLÉRAMA: le délire multimédia. Especial, mai. 1996.

UNION EUROPÉENNE DE RADIO. Troisième congrès international de l'U.E.R. sur la radio et la télévision éducatives. Paris, mar. 1967.

UNESCO. Learn and live: a way out of ignorance for 1,200,000,000 people, jun. 1951.

UNESCO. Rapport d'un comité d'experts pour la télévision. Paris, 7-12 avr. 1952. 
UNGERER, H., COSTELLO, N. Telecommunications in Europe: free choice for the user in Europe's; The Challenge for the European Community. EC Commission: Louxembourg, 1990.

WINKIN, Y. Vers Une Anthropologie de la comunication: la comunication - état des savoirs. Revue Sciences Humaines. Hors Série, n.16, mar./avr. 1997. p. 21. 